Vol. 5, No. 1, 2019

Oksana Kondratyeva

\title{
GESAMTKUNSTWERK AS A FORMULA FOR CREATING ARTISTIC CHARACTER IN ARCHITECTURE BY VOLODYMYR POKROVSKY
}

\author{
Department of Architecture Foundation and Architectural Design \\ Kyiv National University of Construction and Architecture \\ 31, Povitroflotsky Avenue, Kyiv, 03037, Ukraine \\ o.kondratyeva@icloud.com
}

Received: 14.04.2019/Revised: 04.07.2019 / Accepted: 08.07.2019

(C) Kondratyeva O., 2019

Abstract. The concept of architecture as Gesamtkunstwerk exemplifies a model for creating an artistic building's character. This article explores how it is reflected in non-ecclesiastical edifices of Volodymyr Pokrovsky (1863-1924) during the cultural Renaissance of the early twentieth century in Ukraine within the context of the fin de siècle's architecture.

Key words: legacy of Volodymyr Pokrovsky, Gesamtkunstwerk, synthesis of arts, public buildings, the cultural Renaissance of the early twentieth century, Kharkiv, Ukraine.

\section{Introduction}

A style is a reflection of worldview and attitude to life. At the turn of the nineteenth and twentieth centuries, breakthroughs in science such as X-ray discovery; theories of special and general relativity with its empirical proof; discovery of radioactivity and radioactive elements; the notion of noosphere; and the birth of quantum physics significantly changed human understanding of the fundamental laws of nature. It was of utmost importance for human consciousness. Along with many spectacular technological innovations, including electricity and flying machines, scientific discoveries played a formative role in visual arts, literature and architecture. New ideas about space-time left a profound imprint on the way artists and architects viewed the world and interpreted perspectives and proportions. The Art Nouveau convincingly demonstrated this. Each country assimilated Art Nouveau in a different way, adapting it to suit its own historic tradition in terms of design, materials and techniques. Although Art Nouveau was born in Britain, eventually its final chord sounded in Eastern Europe. In Ukraine, which was divided between the Austro-Hungarian and Russian Empires at the time, the style widely varied whilst its specific features depended on the local art school and on the techniques and materials used. It was not until the collapse of the Soviet Union that Art Nouveau became a theme for research. When the Western European art historians were rigorously studying Art Nouveau in the twentieth century, Ukrainian Art Nouveau stayed essentially undiscovered due to the robust Soviet regime. Art Nouveau architecture was coined as the architecture of capitalism whilst Ukrainian Art Nouveau was regarded as a manifestation of nationalism. Once Ukraine gained independence in 1991, a number of scholars began extensive exploration of Art Nouveau architecture, featuring fascinating stylistic peculiarities. One of its most distinctive characteristics was the synthesis of arts - Gesamtkunstwerk ${ }^{6}$, where the emphasis was put on the coherence and homogeneity of every constructive and decorative detail of the building, packing as much decorative art as possible into the premises' spaces.

${ }^{6}$ Gesamtkunstwerk (from German) - coherent and homogenous artistic work: gesamte - overall, whole; die Kunst - art; das Werk - work. 


\section{Basic Theoretical Section}

The term Gesamtkunstwerk was first introduced by a representative of German romanticism, a philosopher and theologian Carl Friedrich Trandorff (1782-1863) in the work Ästhetik oder Lehre von Weltanschauung und Kunst (1827). Wilhelm-Richard Wagner, a German composer and art theorist, developed this concept in his essays Art and Revolution (1849) and The Artwork of the Future (1849). Due to these works, the term Gesamtkunstwerk became known in local artistic circles and spread further afield.

In architecture, there could be no better example of the aspiration towards an integrated and stylistically coherent architectural environment than the architects' houses. The artists and architects of this period expressed their talent in the creation of their own homes - making the home a kind of tangible artistic manifesto, e.g. Philip Webb and William Morris in Red House, Bexleyheath, London, UK, 1859-1860 [1]; William Burges in Tower House, London, UK, 1875-1881 [2]; Oleksiy Beketov in his private house, now the House of Scientists, Kharkiv, Ukraine, 1900-1901; Vladyslav Horodetsky in House with Chimeras, Kyiv, Ukraine, 1901-1903 [3].

A peculiar reflection of such synthetic ideas manifested in the architecture of Volodymyr Mykolayovych Pokrovsky (1863-1924) during the cultural Renaissance of the early twentieth century in Ukraine (Fig. 1). Trained as an architect and artist at the Imperial Academy of Arts in Saint Petersburg [4], he became a junior assistant in the architectural offices of Albert Spiegel in 1888-1891 [5], a leading figure in Kharkiv's architectural realm at the time. From 1891 until 1905, Pokrovsky had diverse architectural experience in Poland [6], leaving behind a remarkable heritage in Sloboda Ukraine. The decade of 19051915 marked heyday of architecture in Kharkiv, the fourth largest city in the former Russian Empire at the time. Although holding a position of the Kharkiv diocesan architect from 1905 until 1918 and designing mostly the religious edifices for the parishes of the Kharkiv Province (currently Kharkiv, Sumy and northern part of Luhansk oblasts in Ukraine), Pokrovsky faced more complex tasks - he designed numerous nonecclesiastical buildings: residential, administrative, educational and cultural. His public buildings of the 1910s chronicle his virtuoso skills, which he developed over time. Pokrovsky, consciously or unconsciously, mirrored the ideas of John Ruskin (1819-1900) - an advocate of the Pre-Raphaelite Brotherhood and the mentor of the Arts and Crafts Movement - yet still in tune with the Zeitgeist of the early twentieth century. He followed the path of Ruskin - "the return of beauty on earth" - established by him in The Seven Lamps of Architecture (1849) and The Stone of Venice (1851-1853). The quintessential characteristic of Art Nouveau architecture - Gesamtkunstwerk - was reflected in Pokrovsky's public buildings of two major cities in Sloboda Ukraine - Kharkiv and Sumy - from 1910 until 1915 (Fig. 2).

The Tree of Life. "Ruskin's view of the importance of direct and careful observation of nature as a means to truth in art, a truth both moral and material" [7] would have been familiar to Pokrovsky. A whole vocabulary of tree imagery, both formally and artistically, is present in every possible expression in the asymmetrical building at 10 Universytetska Street, Kharkiv. In 1912, Pokrovsky fundamentally reconstructed the department store built by Kharkiv municipal architect Olexander Rakov (1840-?) in 1871 and lately rebuilt by Volodymyr Nemkin (1857-1908) in 1889 [8], giving it a new image with a façade bloom, plant shaped reliefs, flamboyant pediment and colonnade. Initially designed as a department store, the premise's space changed its functional purpose to a museum. The house stands out for its symbolic tree design with intersections of stems, leaves and blossoms. The source for the lavish décor on the façade seems to be an amalgam of many influences. There are direct historical associations with the refined reliefs of the Western European Romanesque churches, e.g. cathedral of Saint-Pierre, Angloulême, c. 1136 [9]; the church of NotreDame-la-Grande, Poitiers, from the middle of the twelfth century [10]; or portal archivolts of the abbey church of Sainte-Marie-des-Dames, Saintes, from the second third of the twelfth century [11]. At the same time, it resembles the elegant white-stone carving of Vladimir-Suzdal temples of the twelfth century, such as the Church of Intercession upon the Nerl River and the Cathedral of Saint Demetrius [12]. Mascarons add the sense of spirituality to the blossoming tree and a mist of eternal life. Two thirds of the façade area is covered by glass, which creates transparency indoors and an exterior lightness. The ceiling windows are designed in the form of geometrically intricate iron structures whilst floor ceramic tiles create a rhythm in 
the interior space. Pokrovsky thus convincingly translated the universal language of trees and flowers into the symbol of the Tree of Life. "This premise" - stated the leading Ukrainian scholar Volodymyr Yasiyevych, "has become one of the bright and original manifestations of Art Nouveau in Kharkiv" [13].

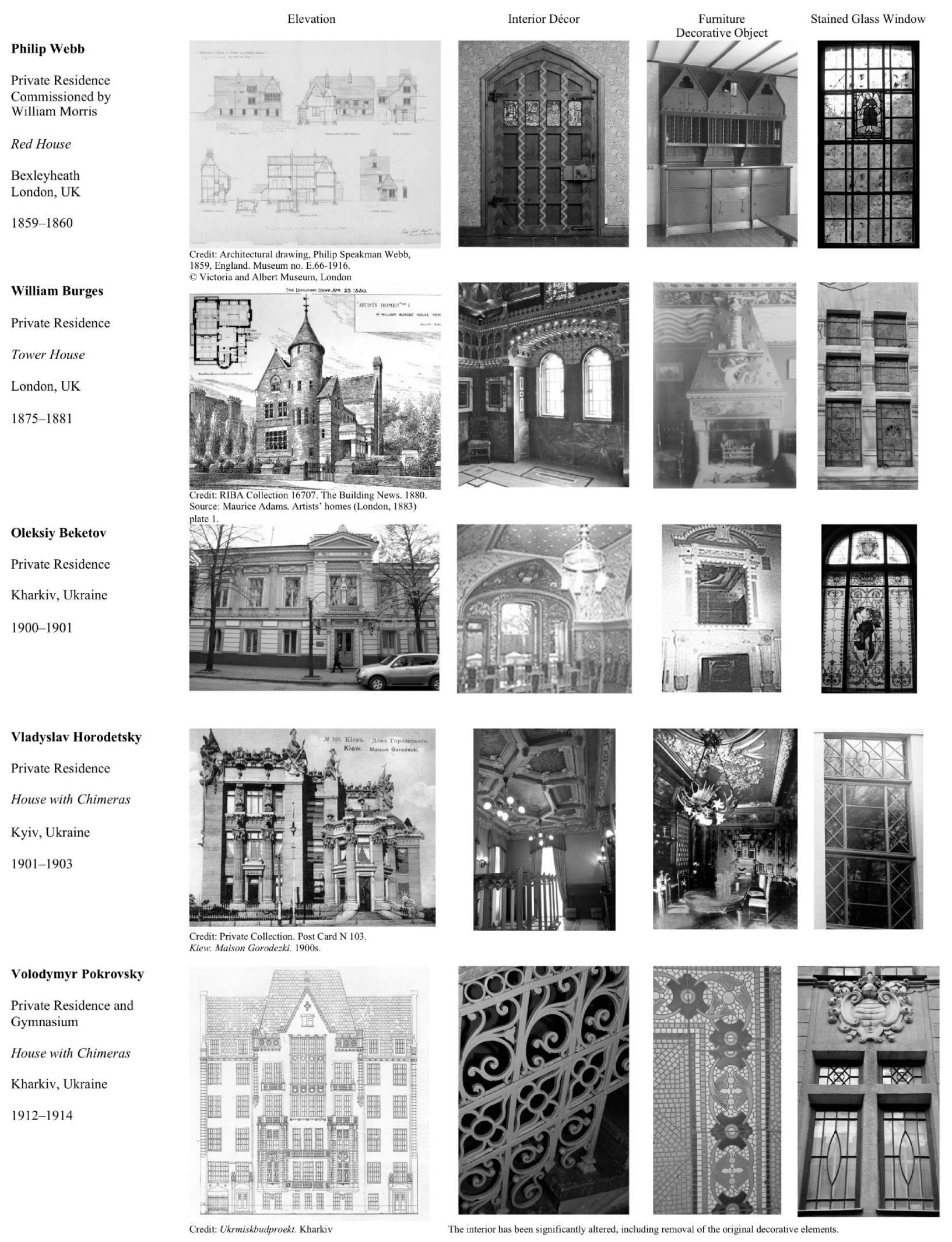

Fig. 1. Architecture as Gesamtkunstwerk in the late nineteenth and early twentieth century 
Elevation

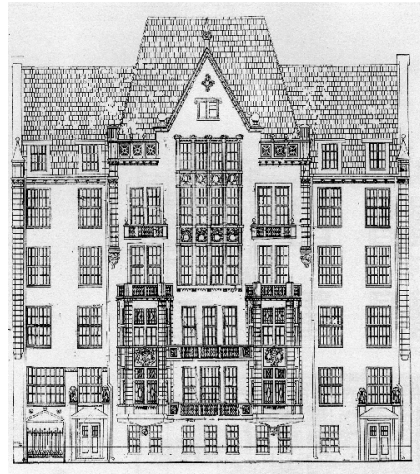

(C) Ukrmiskbudproekt, Kharkiv

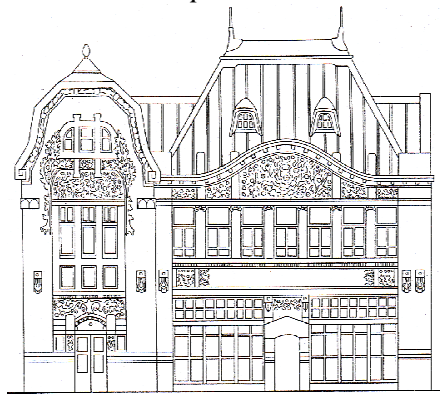

(C) Volodymyr Yasiyevych [13]

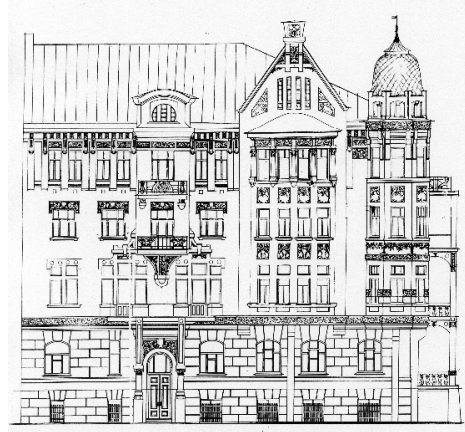

(C) Ukrmiskbudproekt,. Kharkiv

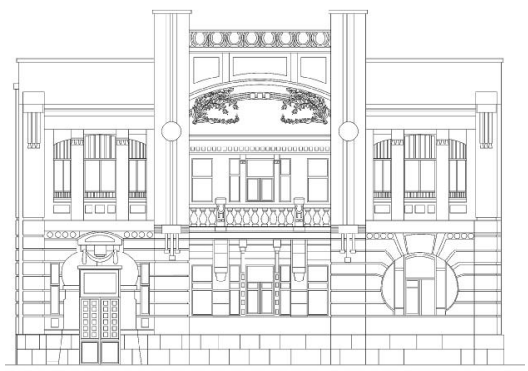

CC Oksana Kondratyeva, 2018

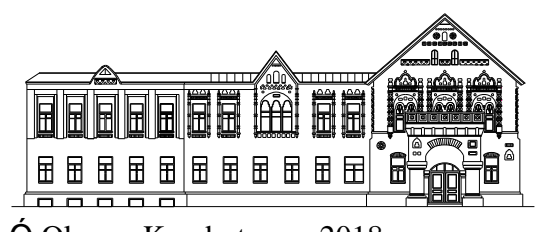

Romenska Str., 1

Sumy

Ukraine

1915
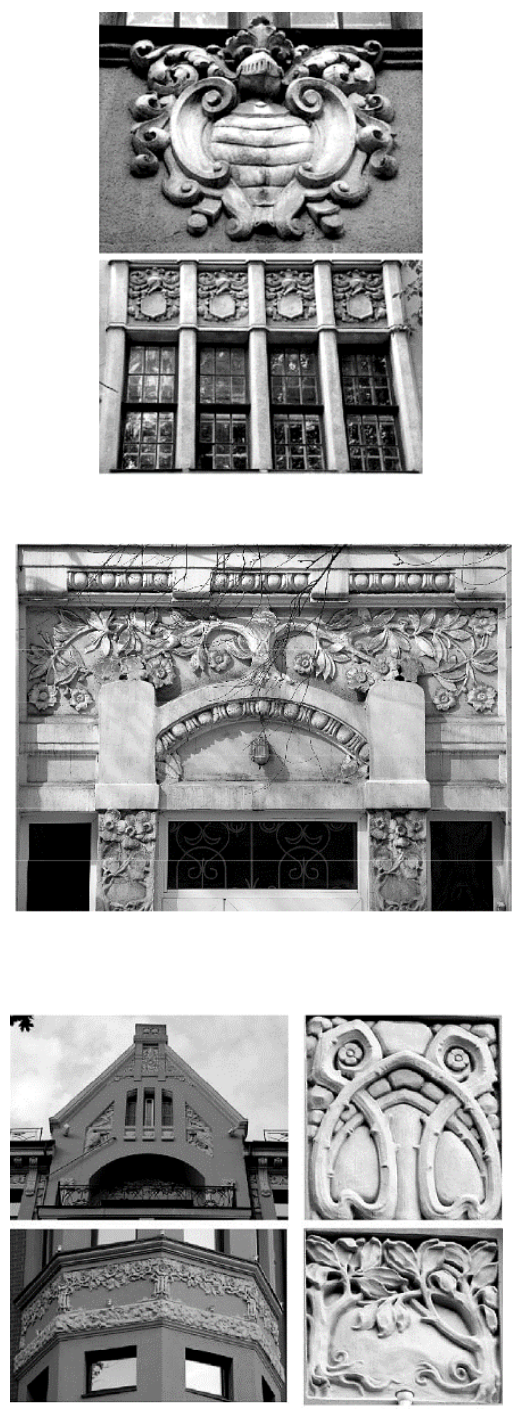

The Tree of Life

The Garden of Eden
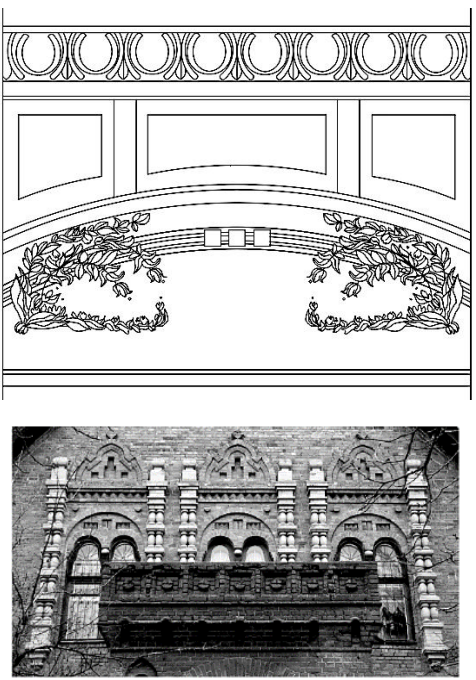

The Gingerbread House

Fig. 2. Institutional and residential buildings. Volodymyr Pokrovsky. Ukraine, 1910-1915 
The Garden of Eden. The corner apartment building at Chernyshevska Street, 66, Kharkiv, is full of narratives that carry their own stories. The impression here is that Pokrovsky sought to render the essence of natural creation at the moment of greatest tension and exuberance. Compositionally dissymmetric architecture is a paraphrase of the Gothic architecture with typical corner turret, bay windows and sharp front-gables. The verticality of structures, underlined by the use of uncovered brick, is accompanied by rich decoration with floral and fauna reliefs, cornices and intricate ornamental friezes and mouldings. They resemble the mysterious wealth of symbols of Romanesque sculptured capitals, e.g. monastery of Santo Domingo in Silos, c. 1085-1100 [14]; Saint-Trophime in Arles, after c. 1150 [15]; the Church of NotreDame in Serrabone, c. 1150 [16]; San Martino in Lucca, c. 1204 [17]; façade relief of San Pietro in Spoleto, c. 1200 [18]. Like a poetic refrain, ornamental details are evident in balcony balustrades, metal railings and fenestration. The content of architecture can be read as the Garden of Eden whilst the atmosphere reflects Pokrovsky's lifelong pursuit to increase his vocabulary of beauty.

A Rainbow. The asymmetrically spatial composition of a two-storey blue-and-white building in Yuriyivska Street, 8 , Kharkiv, can be seen as an illustration of the natural phenomenon - the rainbow. It represents an allegory for Iris - the goddess of the rainbow and the messenger of the Olympian gods in Greek mythology. Pokrovsky defined the essence of naturalism, as where forces operate just as in nature. This building contains those qualities of vitalism or distilled naturalism, which characterised authentic Art Nouveau. Pokrovsky also repeated floral motives in various architectural décor whilst accentuating most narrative detail in the form of a rainbow. Overall, it must be recognised that majestic, impressive premises can be viewed as a new appearance of the ancient symbol in architecture.

The Gingerbread House. The striking asymmetrical administrative premises of the Saint Panteleimon Monastery ensemble in Sumy had a façade in exquisite brickwork layers - echoes of the quattrocento architecture. Reminiscent of the ornaments from Florence and Venice, it has effects of the polychromy of High Victorian Gothic. Richness of arabesque patterns, round decorative inclusions and decorative semi-columns at the corners could be traced to the polychromy in Ruskinian Gothic, e.g. Chester Town Hall, 1863-1869, of architect William Henry Lynn. On the other hand, the building has a touch of the seventeenth-century Russian terem architecture. Its asymmetrical tri-spatial composition represents a crescendo to the lavishly decorated portal with the opensided balcony on the massive columns. The decorative richness of the premises tends to remind us of the Gingerbread House in Hansel and Gretel fairy-tale or a Candyburg's building from The Nutcracker.

A Knight. In the five-storey building at Chernyshevska Street, 79, Kharkiv, Pokrovsky advocated the return to the Middle Ages. His choice for functionally combined premises - educational and residential - was completely harmonious, yet had a strong trace of chivalry. Solemn composition with decorative gable roof in the central part, strong axial alignments riddled with symbolic reliefs represent the legend of a knight. Medievalism became the source of reference but it is not just a reminiscence of medieval art and architecture - this premise could be read as an allegory for a knight. The building has a Gothic air, though in harmony with its functional purpose, showing concern for synthesis and structural essentials. Its Neo-Gothic perpendicularity combined with eccentric fenestration was tempered by a good dose of common sense. Thoughtful functionality of corridor structures was designed for the educational part of the private gymnasium run by the architect's sister Olena Pokrovska, as well as a residential section for the architect's family. The architect sought model dwelling for artistic and social activities, including literary and musical events. Intricate design of the stair railings and the mosaic flooring, illustrates the architect's careful approach to all parts of the building. He incorporated a collection of symbols coded messages to those few who could read it. As a symbolist, he harnessed the power of myth, conjured chimeras, foliage and knights in armour. Besides typical Art Nouveau birds and animals, crooks and foxes, Pokrovsky also integrated bizarre and grotesque creatures. But medievalism was more than a stylistic trait: it was part of Pokrovsky's thinking. He became a committed medievalist.

From 1892 until 1914, Pokrovsky extensively travelled around Western Europe, with a number of visits to Italy [19]. These trips strengthened his knowledge and enabled him to establish contacts with construction factories in Germany and France. In Kharkiv, Pokrovsky's social commitment was genuine and led him and his wife Anna Pokrovska, née Vyrubova, to open a salon and form friendships with artists, poets, composers and musicians, 
philosophers and politicians at the time. A prominent poet and painter Maximilian Voloshin (1877-1932) was one of the family's closest friends [20]. Poetry readings, philosophical and theosophical discussions, musical performances and political debates were frequently held at the Pokrovsky's salon. Furthermore, his range of activities expanded to include painting, drawing, piano playing, organising literary, musical and art public events, publishing books [21], teaching (he was a professor at the Construction Department at the Kharkiv Technological Institute (1919-1922) [22] and at the Architectural Department at the Kharkiv Art College (1921-1924)) [23]; and lately politics (he was elected to the Kharkiv City Duma during the Civil War) [24]. Pokrovsky also expressed his fascination with emerging technologies and was a member of the Automobile Club (1911-1917) [25]. His expertise spanned a number of subject areas that his personality could be regarded as homo univesalis of the early twentieth century.

\section{Results}

If one could weigh the constituents of the Vitruvian Triad in the context of Art Nouveau architecture, then its dominant would be venustas. Richly decorated buildings, fragments of flora and fauna in the ornaments on the façades, fantastic chimaeras, bold use of majolica, stained glass, artistic iron castings and colourful mosaic have little in common with utility and durability. Pokrovsky did not oppose the results of industrial revolution but disliked excessive simplification. Ornament was a strong instrument in interior and exterior décor. The architect placed an emphasis on coherence and homogeneity of decorative and structural elements, which led to integration of premises' macrostructures with microstructures. These were emphasized by widespread use of metal, which the architect generously applied in window decorations, staircase railings and gates. He paid particular attention to fenestration, varying shapes from oculus, arches, trapezia-like hexagonal windows, octagonal shapes in varied compositions, which participated in the rhythm of the whole building's structure. Pokrovsky used themes taken from nature, and also put forward Medieval ideals as his chief frame of reference. Hence, he headed towards synaesthesia, literally a "mutual sensation" [26]. "Art Nouveau condensed synaesthesia into reality: great waves of thick hair, ornamental curves and plant arabesques resemble graphic notation" [27]. The fleur mystique can be viewed as a central leitmotif of his creativity. The mystic flower, this highly conscious inclusion, occurs frequently enough throughout his work to show that they express a constant infatuation with the natural world. He never lost this fascination. It occurs in passages of foliage or breaks through the ornamental mouldings. In non-ecclesiastical architecture, the artistic vision became a working model for Pokrovsky, where the common denominator thematical, philosophical and aesthetic - was the Symbolism and the constant aspiration to move from realia to realiora [28]. Beneath the feast of the façade's decoration - "flickering, feathering, flowering linearism" [29] there was a sinuous, practical and precise approach. Underneath it, all was a master builder and at the heart of his work, there was a form. He looked beyond Ukrainian and Russian tradition, to the art of European Medieval architecture, glittering mosaics of Byzantine churches and European wooden architecture of the seventeenth century. Above all, he designed functional buildings. The study considered Pokrovsky's public buildings of 19101915 for the first time in the context of the British and Continental Art Nouveau architecture. The peculiarities of Ukraine's Art Nouveau architecture of the early twentieth century could be a significant addition to the European history of architecture as a whole.

Discussion. The public buildings show Pokrovsky to be a disciple of the fin de siècle. Although he chose the language of symbols, for him "symbolism was far more than a mere aesthetic tendency; rather, it represented an entire world view and a way of life which engaged intense dreams, religious explorations, decorative rhetoric, and various kinds of metaphysical creativity" [30]. Like many scientific discoveries, which proved that one could see the world beyond its outer appearance, the same is true with architecture: one can see the allegorical image beyond the construction's structure. In fact, Pokrovsky's initial reputation was formed as an original designer of religious edifices, including his masterpiece Three Saints Church in Kharkiv, 1907-1915 [31]. It would be worthwhile to consider Pokrovsky's ecclesiastical buildings within the context of architecture as Gesamtkunstwerk. Pokrovsky occasionally designed the interior details and appointments for his ecclesiastical buildings, for example, iconostasis [32] and ferramenta window traceries. Nevertheless, the combination of other 
decorative parts such as geometrical patterns of flooring tiles and wall painting were the results of his teamwork with craftsmen and artists. Yet it illustrates another sign of integration of the arts and crafts in architecture. Furthermore, a comparative study of Pokrovsky's religious buildings with Aleksei Shchusev's interior of Saints Anthony and Theodosius of Pechersk Church, Kyiv Pechersk Lavra, Ukraine, 1902-1910 [33], as well as exterior and interior of Trinity Cathedral, Pochayev Lavra, Ukraine, 1906-1912, would make a fascinating case study.

Conclusion. Pokrovsky's non-ecclesiastical buildings in Ukraine of 1910-1915 can be described as the true essence of Art Nouveau and illustrate the manifesto of the new style in Sloboda Ukraine. He put an emphasis on shaping an artistic image of a building. The parts of his buildings are intimately interconnected and explicable only by reference to the whole. Each premises constituted to the same principle - symbolism. On the other hand, he achieved a masterly balance between constructive principles and décor whilst felt liberated to use all the construction elements considered important. However, Pokrovsky never succeeded in freeing himself entirely from tradition and academism, designing premises with Neo-Classical, Neo-Romanesque or Neo-Gothic elements. Art Nouveau was part of a larger trend in Ukraine's territory, where Kharkiv's architectural school illustrated its distinctive features, notable in the history of the European architecture. Volodymyr Pokrovsky formed the characteristic visage of an era, managed to produce an overall sense of design, which both fascinated and unified whilst speaking a universal language. He was, thus, a true Art Nouveau architect, an architecte d'art.

\section{References}

[1] Victoria and Albert Museum: Museum no. E. 66-1916. Webb Philip Speakman. Architectural drawing, London, 1859.

[2] RIBA: Collection 16707. The Building News. 1880. Source: Maurice Adams. Artists' homes plate 1. London, 1883.

[3] Malakov D. Horodetsky. Vyklyk Budivnychogo. Grani-T, Kyiv, 2008, 176.

[4] State Russian Historical Archive. Fond 789, opis' 11, edinitsa sberezheniya 116, stranitsy 4, 43, 60.

[5] Ibid. Fond 789, opis' 11, edinitsa sberezheniya 116, stranitsa 47.

[6] Ibid. Fond 1343, opis' 3, edinitsa sberezheniya 1743, stranitsa 48, 48 obratnaya, 49.

[7] MacCarthy F.: The Last Pre-Raphaelite. Edward Burne-Jones and the Victorian Imagination. Faber and Faber, London, 2011, 38.

[8] Leibfreyd A. Yu., Polyakova Yu.Yu.: Kharkov. Ot Kreposti Do Stolitsy. Folio, Kharkov, 2008, 129.

[9] Toman R. Ed.: Romanesque. Architecture. Sculpture. Painting. Ullmann \& Könemann.Tandem Verlag GmbH, Königswinter 2007, 266.

[10] Ibid. 267.

[11] Ibid. 271.

[12] Ermakova S. O.: Vladimir i Suzdal. Veche, Moskva, 2008, 73-82, 90-100.

[13] Yasiyevich V. E.: Arhitektura Ukrainy na Rubezhe XIX-XX Vekov. Budivelnyk, Kyiv, 1988, 155.

[14] Toman R. Ed.: Romanesque. 338.

[15] Ibid. 286.

[16] Ibid. 279.

[17] Ibid. 306.

[18] Ibid. 307.

[19] State Archive of Kharkiv Oblast. Fond R-820, opys 1, odynytsya zberezhennya 1294.

[20] Fedorova E. S.: Kak v Kaple Dozhdya. Labirint, Moskva, 2011, 175-176.

[21] Rozvadovskiy L. E. Vaterpas, 1995. N1, 42-45.

[22] State Archive of Kharkiv Oblast. Fond R-169, opys 1, odynytsya zberezhennya 101.

[23] State Archive of Kharkiv Oblast. Fond R-820, opys 1, odynytsya zberezhennya 1294, 336.

[24] Novaya Rossiya. Kharkovskaya ezhednevnaya gazeta. N147. 13 noyabrya 1919, 3.

[25] Grigoryev D.: Manuscript. Kharkivska Derzhavna Naukova Biblioteka, Kharkiv, 2014.

[26] Fahr-Becker G.: Art Nouveau. Könemann. Imprint of Tandem Verlag GmbH, Königswinter 2004, 16.

[27] Ibid.

[28] Bowlt J. E.: Moscow and St. Petersburg in Russia's Silver Age. Thames \& Hudson, London, 2008, 92.

[29] Fahr-Becker G.: Art Nouveau. 13.

[30] Bowlt J. E.: Moscow and St. Petersburg in Russia's Silver Age. 67.

[31] Lizan I., Novgorodov V. E., Leybfreyd A. Yu., Denisenko O. I.: Trehsvyatitelskaya Tserkov v Kharkove. Kharkov, $1999,60$.

[32] Ibid. 27.

[33] Pitateleva O. V., Lytvynenko Ya. V.: Lavrskyi Modern. Ornamenty Trapeznoyi Palaty i Tserkvy. Sofiya, Kyiv, $2014,144$. 


\title{
«ГЕЗАМТКУНСТВЕРК» ЯК ФОРМУЛА СТВОРЕННЯ АРХІТЕКТУРНО-ХУДОЖНЬОГО ОБРАЗУ В БУДІВЛЯХ В. М. ПОКРОВСЬКОГО
}

\begin{abstract}
Анотація. Наукові відкриття кінця ХІХ - початку XX століття докорінно змінили світогляд та розуміння тонкої структури всесвіту. Нове світосприйняття було взаємопов'язане з «ренесансом» в образотворчому мистечтві, музииі, театрі, архітектурі, філософії, а синтез різноманітних мистеитв і мистецтв з наукою, філософією та релігією стали чентральними у творчості чималої когорти митиів fin de siècle. Це був час всеосяжної «культурної револючії». Термін Gesamtkunstwerk вперше увів до вжитку представник німеиького романтизму, філософ, теолог Карл Фрідріх Трандорфф (1782-1863). Німецький композитор і теоретик мистецтва Вільгельм-Ріхард Вагнер розвинув июо концепиію в есеях «Мистеитво і революиія» та «Твір мистеитва майбутнього» 1849 року. Саме завдяки прачям К. Ф. Трандорффа та В. Р. Вагнера термін Gesamtkunstwerk став відомим у мистецьких і мистеитвознавчих колах. Своєрідним віддзеркаленням иих синтетичних ідей став розвиток концепиії «архітектура як Gesamtkunstwerk», яку втілювали, створюючи иілісні образи-будівлі та універсальні простори, архітектори Філіпп Вебб («Червоний будинок», приватний будинок, Лондон, 1859-1860 рр.); Вільям Берджес («Будинок Башта», приватний будинок, Лондон, 1875-1881 рр.); Олексій Бекетов (приватний будинок, нині - «Будинок вчених», Харків, 1900-1901 рр.), Владислав Городецький, (приватний будинок, нині «Будинок з химерами», Київ, 1901-1903 рр.).

Творча універсальність була притаманна і архітектору-художнику В. М. Покровському (1863-1924). Амплітуда його життєтворчості відзначена надзвичайним розмахом: архітектор-художник, дизайнер (декоратор), реставратор, керівник численних будівельних проектів, громадський діяч, викладач - професор Харківського технологічного інституту 1919-1922 років, професор Харківського художнього технікуму 1921-1924 років. В. М. Покровському була властива важлива, глибинна риса творчої еволюиї: випускник Імператорської академії мистецв, єпархіальний архітектор Холмсько-Варшавської і Харківської єпархій, він став одним із найвизначніших майстрів модерну в Украӥні.

Iдея «архітектура як Gesamtkunstwerk» найвиразніше віддзеркалилася у його архітектурних творах, які були створені під час активної проектної практики на теренах Слобідської України упродовж 1906-1915 років. Властивості «всеосяжного твору» були притаманні як його ијиільній, так і культовій архітектурі, проте стаття зосереджує увагу на громадських та житлових будівлях 1910-1915 років у Харкові та Сумах. В архітектурних формотворах архітекторхудожник вдало поєднує технічні досягнення; будівлі вирізняються архітектурною «полістилістикою», гармонійним синтезом різноманітних видів декоративно-ужиткового мистецтва. Кожна із цих споруд - особлива, але між ними можна почути внутрішню риму - вони є архітектурно-художніми образами. Рівень їх естетичної інтенсивності підкреслює висоту творчої думки В. М. Покровського, його міждисииплінарне мислення у створенні всеосяжного твору.
\end{abstract}

Ключові слова: творчість архітектора-художника В. М. Покровського, єпархіальний архітектор, синтез мистецтв, архітектурно-художній образ, культурний ренесанс початку ХХ століття, Харків. 